\title{
ANALYTIC SIGNAL AND RESERVOIR MODEL OF HATUASA-TALANGHAHA HOT SPRING, TULEHU, AMBON, INDONESIA BASED ON MAGNETIC DATA INVERSION
}

\author{
S. Sismanto \\ Department of Physics, Faculty of Mathematics and Natural Sciences, \\ Universitas Gadjah Mada, Yogyakarta 55281, Indonesia \\ R. Lewerissa \\ Department of Physics, Faculty of Mathematics and Natural Sciences, \\ Papua University, Manokwari, Papua Barat 98314, Indonesia
}

\begin{abstract}
The earth magnetic field study has been carried out in Suli and Tulehu, Ambon island to study the geothermal systems that apply in the region, specifically the reservoir model in the Hatuasa and Talanghaha hot springs. These hot springs are located on the fault line, including the Banda and Banda-Hatuasa faults, southwestnortheast. The study was conducted by subsurface inversion modeling after performing an analytic signal analysis of magnetic data. The total magnetic field intensity in the geothermal regions of Suli and Tulehu ranges from -656 nT to $310 \mathrm{nT}$, which is dominated by high anomalies in Tulehu. Meanwhile, the reduce to pole (RTP) magnetic anomaly ranges from $-1069.20 \mathrm{nT}$ to $662.78 \mathrm{nT}$, which is dominated by low anomalies, where the Hatuasa and Talanghaha hot springs are at low to middle anomalies. The analytic signal analysis of magnetic data clearly shows the geological boundaries in the study area. Inversion modeling of magnetic anomaly produces contrast susceptibility of rocks ranging from -0.042 SI to 0.043 SI. The reservoir layer as a place for geothermal fluid under the Hatuasa - Talanghaha hot springs is generally associated with low susceptibility contrast at depths reaching 500 m-1000 $m$. The cap rock is $500 \mathrm{~m}$ deep with a susceptibility value of -0.0035 SI-0.0065 SI and the heat source is thought to originate from igneous intrusion in the study area.
\end{abstract}

Keywords: Magnetic, Inversion, Reservoir, Analytic Signal, Tulehu.

Cite this Article: S. Sismanto and R. Lewerissa, Analytic Signal and Reservoir Model of Hatuasa-Talanghaha Hot Spring, Tulehu, Ambon, Indonesia Based on Magnetic Data Inversion. International Journal of Civil Engineering and Technology (IJCIET), 11(1), 2020, 137-145. https://iaeme.com/Home/issue/IJCIET?Volume=11\&Issue=1 


\section{INTRODUCTION}

Ambon Island is between Buru Island in the west and Seram Island in the north of eastern Indonesia. Geologically, Ambon Island has two different parts, namely Hitu in the north and Leitimor in the south [1]. Hitu is dominated by volcanic rocks, including dacite-bearing cordierite, while Leitimor consists mostly of upper triad greywacke and limestone metamorphic rocks, which are tectonically uplifted by ophiolitic rocks [1]; [2]. The existence of shallow magmatic heat sources is not described at this time, but many hot springs appear in the eastern part of the Ambon Island, namely Suli and Tulehu [3]. Suli and Tulehu belong to Central Maluku regency administrative area, which is located at an altitude of $76 \mathrm{~m}$ above the sea level. Most of the geothermal manifestations in this region are hot springs and there are also fumaroles and altered rocks along the Huwe, Tulehu, Banda and Banda-Hatuasa faults [4].

Faults and fractures have an important role in the localization and evolution of the hydrothermal system. Hydrothermal activities highly depend on interactions between heat sources, fluid circulation, and permeable layer pathways [5]. In the Suli and Tulehu geothermal fields, several related studies have been carried out including geological, geochemical, CSAMT, and magnetotelluric (MT) surveys [6-7]. Besides, drilling of one exploration well had reached a depth of $932.67 \mathrm{~m}$. The results of previous studies have not been able to describe comprehensively about the geological structures that affect the geothermal system in the study area. Besides that, the study area is still limited in Tulehu, so it needs to be extended to Suli which also has many manifestations of hot water on the surface.

Our study applies a magnetic method for evaluating the underlying geological structures related to the reservoir layers of the Hatuasa and Talanghaha hot springs in Tulehu Village, Ambon, Indonesia. The application of the magnetic method in geothermal exploration in several places shows significant results to delineate the fault and fracture zones associated with geothermal reservoirs. Also, the application of this method is more economical [8] Determination of the reservoir model is based on the inversion modeling of magnetic anomaly data, which is preceded by the analytic signal analysis to determine the geological structure boundaries in the study area.

\section{GEOLOGY OF STUDY AREA}

The geothermal areas of Suli and Tulehu are in the eastern part of the island of Ambon, including the administrative area of Central Maluku Regency. Ambon Island is located between the Buru and Seram islands in eastern Indonesia, which represent pieces of the old continental crust starting from the island of Papua [9]. Ambon Island consists of two different geological sections, namely Leihitu in the north and Leitimor in the south. Leihitu has volcanic geological features composed of dacites, which are locally covered by coral deposits and quarterly alluvium. Leitimor consists mainly of upper grey Triassic and limestone metamorphoses, which are tectonically covered by ophiolitic rocks in the southern part of Ambon Island [1,10]. The geology in the Suli and Tulehu geothermal fields consists of 13 units namely sandstone, Tanjung basalt lava, Salahutu-l dacitic lava, Huwe pyroclastic, Simalopu mountain pyroclastic, Salahutu mountain pyroclastic, Kadera mountain pyroclastic, Eriwakang mountain pyroclastic, limestone, and Alluvium [6]. 


\section{METHODOLOGY}

\subsection{Magnetic Data Acquisition and Processing}

This study uses data on measurements of the earth magnetic field in the Suli and Tulehu geothermal fields in 2017 which include several hot springs such as Hatuasa and Talanghaha [11]. Magnetic field measurements were conducted at 152 stations on southwest-northeastdirection with a measurement grid spacing between 200 to $400 \mathrm{~m}$ (Figure 1). The observation data of total magnetic field were corrected using diurnal variation and IGRF corrections to eliminate the influence of the main magnetic field, thus obtaining anomalies of total magnetic field intensity. Inclination angle, declination, and total magnetic field in the study area are $1.29^{0},-23.47^{0}, 41670.3 \mathrm{nT}$. For the reduction to the poles of the inclination and declination angles used are $90^{\circ}$ and $0^{\circ}$.

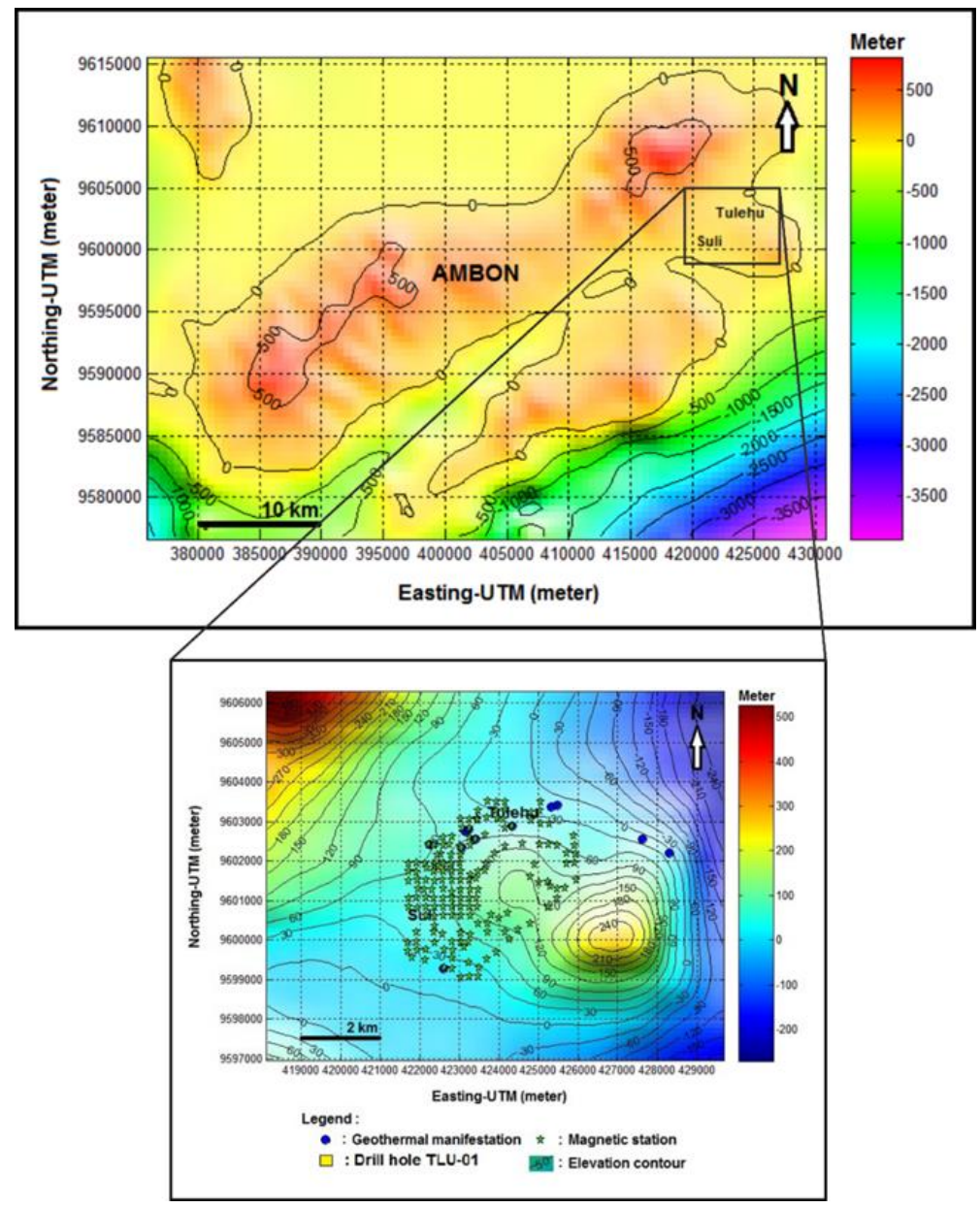

Figure 1 Distribution map of magnetic field measurement stations in Suli and Tulehu, Ambon, Indonesia.

The total magnetic intensity in the study area ranged from -656 nT to $310 \mathrm{nT}$ southwestnortheast. Low magnetic anomalies were found in Suli, increasing towards Tulehu (Figure 2a). To get a symmetrical magnetic anomaly located right above the anomalous object, the total magnetic field intensity needs to be reduced to the poles. This method was conducted to change the total magnetic field anomaly into a simple anomaly, thereby eliminating distortion due to the inclination angle of the magnetic field [12]. 
The reduced magnetic anomaly to the poles in Suli and Tulehu has negative to positive values ranging from $1069.20 \mathrm{nT}$ to $662.78 \mathrm{nT}$ (Figure 2b), dominated by low anomalies, where the Hatuasa and Talanghaha hot springs are in the low to moderate anomalies. Low magnetic anomalies are thought to be associated with alteration rocks exposed on the surface. Medium magnetic anomalies are thought to be associated with coral limestone while high anomalies are associated with Eriwakang pyroclastic igneous rocks exposed on the surface.
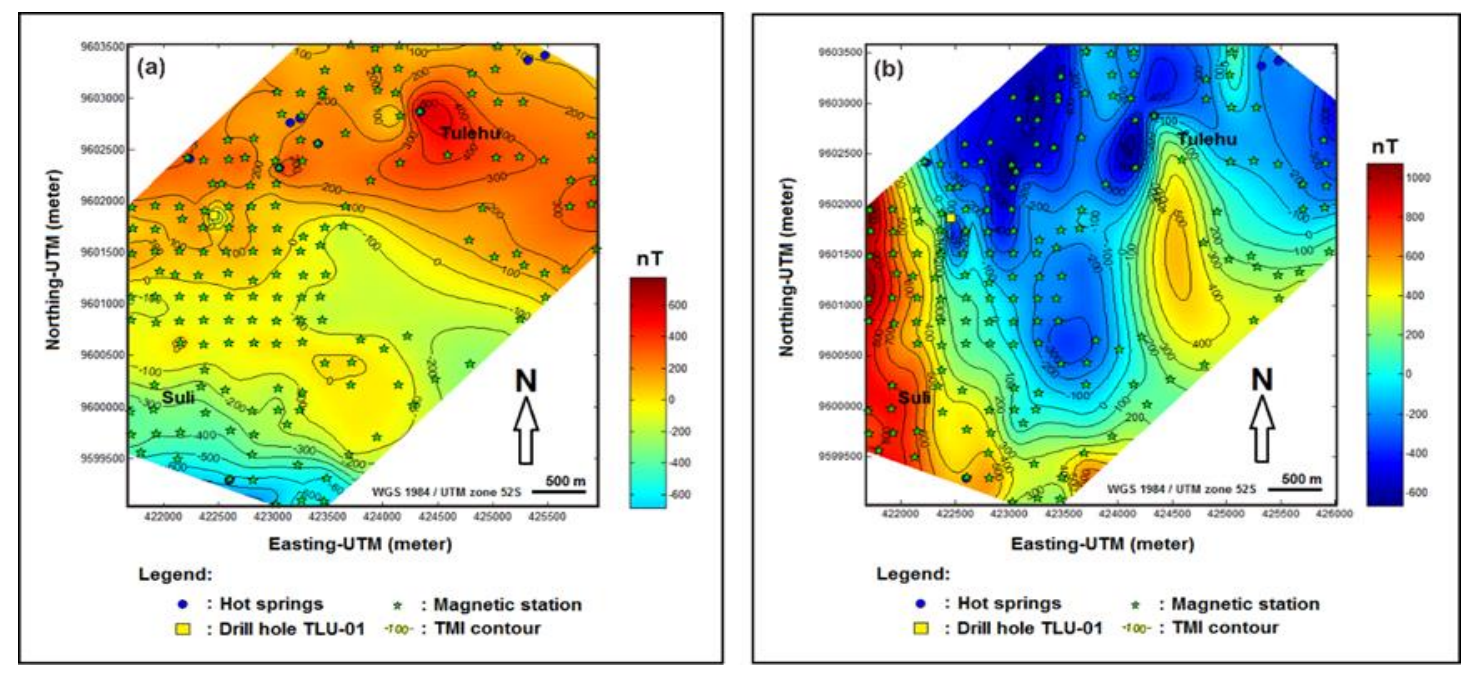

Figure 2 Anomaly of total magnetic field intensity in Suli and Tulehu; (b) Magnetic anomaly reduction to poles with total magnetic field of $41670.3 \mathrm{nT}$, inclination of $1.29^{\circ}$, and declination of $23.47^{0}$.

For magnetic inversion modeling, RTP magnetic anomaly data are separated between regional and residual anomalies. Regional anomalies are contributions from deep and broad structures while residual anomalies are influenced by shallow and small structures [13]. Our study uses the upward continuation method for separating anomalies at a height of $1000 \mathrm{~m}$ from the surface. Regional magnetic anomalies with negative to positive values range from $87.96 \mathrm{nT}$ to $340.67 \mathrm{nT}$. These anomalies with a Southwest-Northeast direction and an open contour pattern have the lowest value in Tulehu which rises towards Suli (Figure 3a). Residual magnetic anomalies have more complex patterns with values ranging from -642.76 nT to $819.78 \mathrm{nT}$. In general, residual magnetic anomalies have the same pattern as RTP magnetic anomalies that are dominated by low anomalies in Suli and Tulehu. The TLU-01 exploration well and surface hot springs are in a low negative magnetic anomaly (Figure $3 \mathrm{~b}$ ).
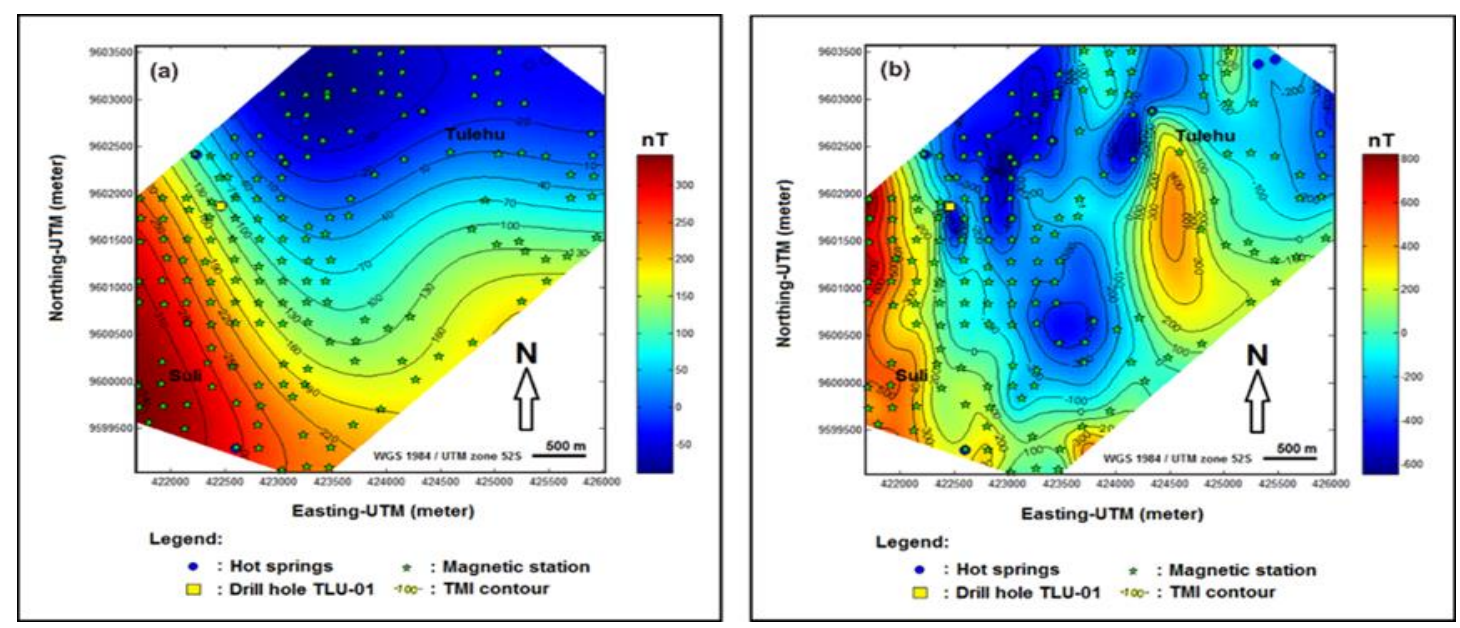
Figure 3 Separation of RTP magnetic anomalies using upward continuation at an altitude of $1000 \mathrm{~m}$ (a) regional anomalies; (b) residual anomalies.

\subsection{Magnetic Anomaly Analytic Signal}

Analytic signals can be applied to magnetic data and their gradients along the $x, y$, and $z$ directions. The amplitude of the first vertical derivative of the analytic signal in the $x$ and $y$ directions heightens the edge of the anomalous cause. The analytic signal analysis on magnetic data aims to delineate the boundaries of geological structures such as contacts and faults found in Suli and Tulehu, Ambon by determining the maximum amplitude value of the analytic signal which is a combination of horizontal and vertical gradients [14]. For magnetic fields, the amplitude of 3-D analytic signals at the locations $(x, y)$ can be derived from three orthogonal total magnetic field gradients using the equation $[15,16,17]$ :

$$
|A(x, y)|=\sqrt{\left(\frac{\partial T}{\partial x}\right)+\left(\frac{\partial T}{\partial y}\right)+\left(\frac{\partial T}{\partial z}\right)}
$$

where $A(x, y)$ is the amplitude (absolute value) of the analytic signal at the positions ( $x$, $y$ ), and $T$ is the observation magnetic field.

\subsection{Magnetic Inversion Modeling}

Three-dimensional (3D) inversion modeling of the earth magnetic fields in Suli and Tulehu was done using the Oasis Montaj software v. 8.4 from Geosoft Inc. Inversion modeling begins based on the inversion modeling equation developed by $[18,19]$.

The main input parameters are model geometry, inclination angle of $1.29^{0}$, declination of $23.47^{\circ}$, and the total magnetic field of $41670.3 \mathrm{nT}$. For the reduction to the poles, the inclination and declination angles used are $90^{\circ}$ and $0^{\circ}$. Cell numbers for the $x, y$, and $z$ axes are 43, 45, and 23 with a voxel size of $100 \times 100$. Magnetic anomalies on the earth surface that are related to subsurface susceptibility values can be expressed in the form of linear relationships as (Li and Oldenburg, 1996) [18]:

$$
\boldsymbol{d}^{\text {obs }}=\overline{\boldsymbol{G}} \boldsymbol{\kappa}
$$

where $\boldsymbol{d}=\left(\boldsymbol{d}_{1}, \ldots, \boldsymbol{d}_{\boldsymbol{N}}\right)^{\boldsymbol{T}}$ is the observation data vector and $\boldsymbol{\kappa}=\left(\boldsymbol{\kappa}_{1}, \ldots, \boldsymbol{\kappa}_{\boldsymbol{M}}\right)^{\boldsymbol{T}}$ is the susceptibility value in each cell. $\overline{\boldsymbol{G}}$ is a sensitivity matrix with elements which are quantitatively the contribution of the susceptibility unit to the $\mathrm{j}$-cell to the $\mathrm{i}$ point of measurement (datum).

\section{RESULTS AND DISCUSSION}

\subsection{Magnetic Anomaly Analytic Signal}

The analytic signal analysis from the residual magnetic anomaly data in the RTP (reduce to pole) has been carried out to obtain clarity of the boundaries of the geological structure in the study area. This analytic signal utilizes magnetic gradient components in the $x, y$, and $z$ direction components which are processed using Magpick software. The analytic signal is positive with a range of values between $14 \mathrm{nT} / \mathrm{m}$ to $23 \mathrm{nT} / \mathrm{m}$ (Figure 4). These results show that the geological structure which is thought to be the result of igneous rock intrusion (dashed red circle) as a source of geothermal energy is associated with medium to high amplitudes of analytic signals. In general, the geothermal manifestations in the form of Hatuasa and Talanghaha hot springs located on the Banda and Banda-Hatuasa fault lines are at the boundary between the high amplitudes of southwest-northeast. The analytic signal of 
the magnetic field can delineate the fault structure and the indication of igneous intrusion in the study area.

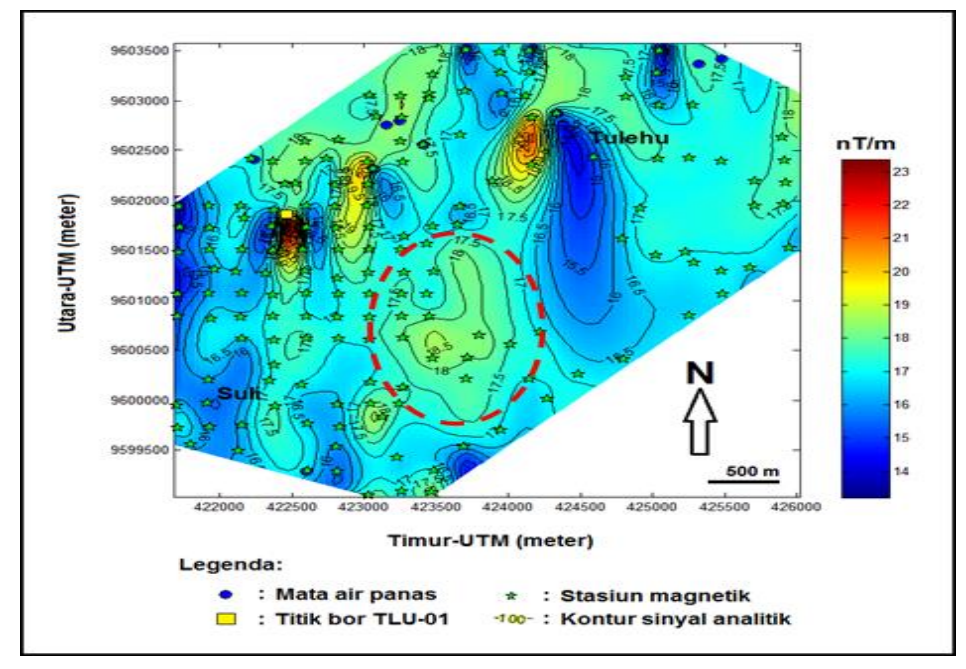

Figure 4 Analytic Signals of Residual Magnetic Anomalies in Suli and Tulehu, Ambon.

The results of the magnetic data analytic signal are in accordance with the analytic signal gravity data for the study area that has been carried out by Lewerissa et al., (2018) [20].

\subsection{Subsurface Three-Dimensional (3-D) Model}

The results of magnetic anomaly three-dimensional (3D) inversion of indicating subsurface models in the geothermal regions of Suli and Tulehu are shown in Figure 5 with a contrast of the overall susceptibility of the resulting models ranging from -0.042 SI to $0.043 \mathrm{SI}$.

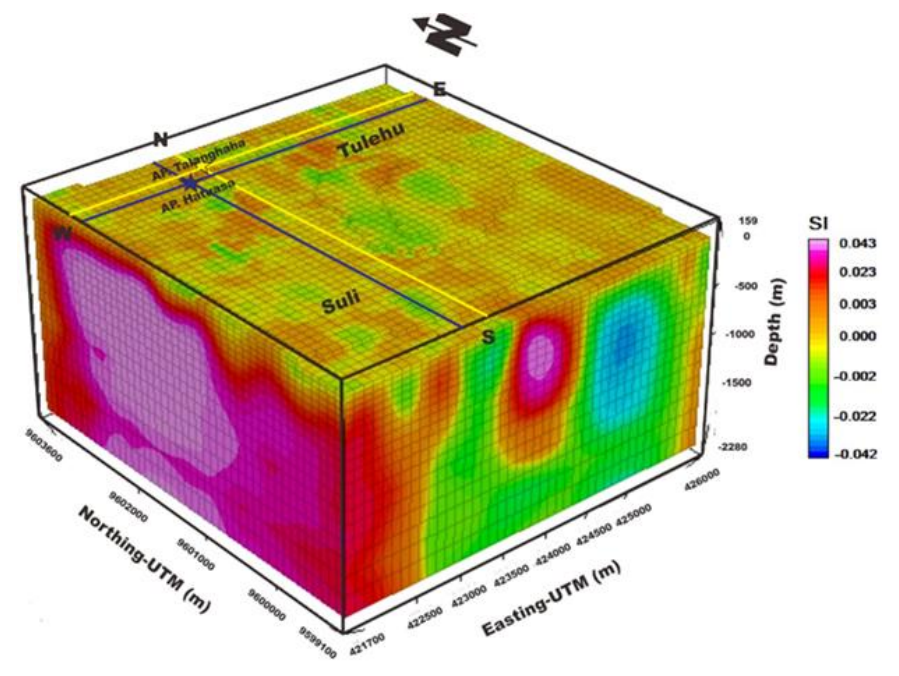

Figure 5 3-D Subsurface Model in Suli and Tulehu Based on Magnetic Inversion

Contrast susceptibility on the surface ranges from -0.0035 SI to 0.0065 SI at an elevation of $159 \mathrm{~m}$ at the topography to a depth of $500 \mathrm{~m}$, which is thought to be a cap rock layer in the study area. The negative susceptibility contrast is in Suli while positive contrast dominates in Mount Eriwakang and Tulehu areas. The susceptibility contrast value from -0.041 SI to 0.043 SI is thought to be the upper part of the geothermal reservoir layer which stores hot fluids at depths between $500 \mathrm{~m}$ and $1000 \mathrm{~m}$. In this condition, the rocks have undergone alteration so that the magnetic properties are reduced or lost due to the influence of heat source rocks. The 
position of the Hatuasa and Talanghaha hot springs in Tulehu contrasts with the low negative rock susceptibility.

At depth of more than $1000 \mathrm{~m}$, it is dominated by the contrast of negative rock susceptibility in Suli and positive contrast in Mount Eriwakang and Tulehu. This layer has a contrast value of rock susceptibility ranging from -0.0395 SI to 0.0371 SI with a pattern that is generally the same as the previous layer. High susceptibility contrast still exists in the western part of Suli and dominates in Tulehu. The low negative susceptibility contrast in the middle between Suli and Tulehu extends from north to south with values ranging from -0.041 SI to -0.0225 SI. This low negative susceptibility contrast is thought to still be a geothermal reservoir layer to a depth of $2000 \mathrm{~m}$. To reinforce the Hatuasa and Talanghaha hot spring reservoir models, two north-south and west-east trending cross-sections have been made in the coordinates of $03.593650^{\circ} \mathrm{S} ; 128.308060^{\circ} \mathrm{E}$ (Figure 6), and $03.593270^{\circ} \mathrm{S} ; 128.308880^{\circ} \mathrm{E}$ (Figure 7).

In general, the 2-5D subsurface models of the Hatuasa and Talanghaha hot springs have the same pattern because the distance between the two geothermal manifestations is still close together. In addition, the subsurface model of the geothermal reservoir layer from the results of the residual magnetic anomaly data is in conformity with the model results from the MT method survey [6,7], which states the alteration zone is associated with low rock resistivity, whereas resistivity height correlates with geothermal reservoirs which reach a depth of $1 \mathrm{~km}$.

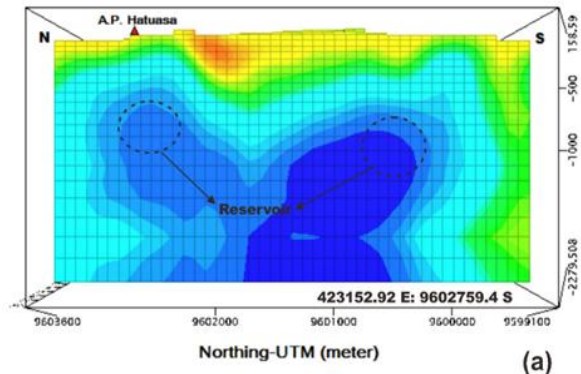

(a)

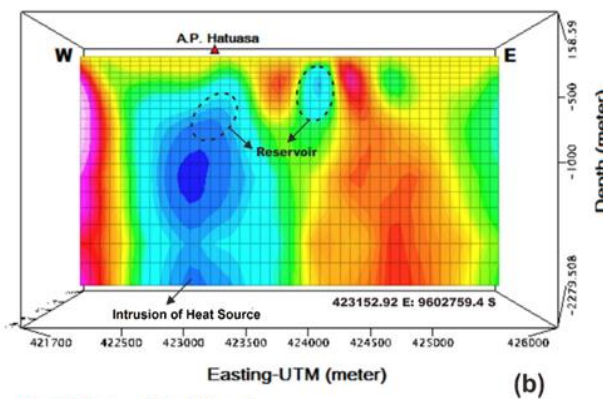

$\Delta$ : Hot Springs (A.P. Hatuasa)

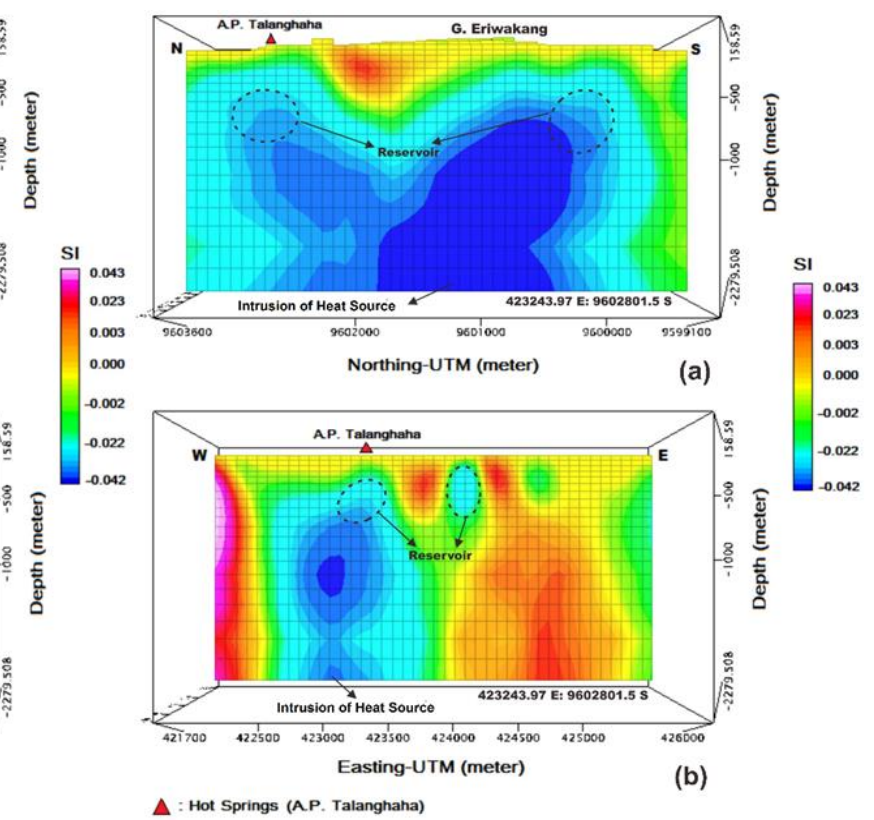

Figure 6 2.5-D Subsurface Model that Cuts Perpendicular to the Hatuasa Hot Spring at Coordinates of $03.5936500 \mathrm{~S} ; 128.3080600 \mathrm{E}$.

Figure 7 2.5-D Subsurface Model that Cuts Perpendicular to the Talanghaha Hot Spring at Coordinates of 03.5932700 S; 128.3088800 E.

\section{CONCLUSION}

The total magnetic field intensity in the geothermal regions of Suli and Tulehu is negative to positive, ranging from $-656 \mathrm{nT}$ to $310 \mathrm{nT}$ which is dominated by high anomalies in Tulehu. The position of the Hatuasa-Talanghaha hot springs along the normal faults of Banda and Banda-Hatuasa is in a low magnetic anomaly in the RTP, thought to be a geothermal alteration zone. The analytic signal analysis from residual magnetic anomaly data in the RTP clearly shows the boundaries of geological structures in the study area, generally associated 
with maximum signal amplitude. The results of three-dimensional inversion (3-D) magnetic anomalies produce contrast susceptibility of subsurface rocks ranging from - 0.042 SI to 0.043 SI. The reservoir layer as a place for geothermal fluid under the Hatuasa-Talanghaha hot springs is generally associated with low susceptibility contrasts, thought to be intensely warmed up by the heat source rocks below. The depth of the reservoir layer is estimated to be more than $500 \mathrm{~m}$ to $1000 \mathrm{~m}$. The cap rock is $500 \mathrm{~m}$ deep with a susceptibility value of -0.0035 SI to $0.0065 \mathrm{SI}$ and the heat source is thought to originate from igneous intrusion in the study area.

\section{ACKNOWLEDGEMENTS}

Thanks to the government of Maluku province and PT. PLN Maluku and North Maluku regions have permitted to conduct our research in Suli and Tulehu. The authors also thank Geosoft Inc, which prompted the invitation of authors to use Oasis Montaj software for magnetic inversion modeling for one month. Also, the author is grateful to the F.MIPA Universitas Gadjah Mada for BPPTNBH research grant 2019.

\section{REFERENCES}

[1] Honthaas, C., Maury, C, Rene. Priadi, B. Bellom, H., Cotten, J., The Plio - Quaternary Ambon arc , Eastern Indonesia., Tectonophysics. 301, 1999, pp.261.

[2] Van Bemmelen, R, W. The Geology of Indonesia, Vol. 1A.Goverment Printing Office, The Hague, 1949, pp 732.

[3] Marini, L., Susangkyono, A, E. Fluid Geochemistry of Ambon Island (Indonesia), Geothermics, 1999; Vol. 28: 184-204.

[4] Vandani, K, P, C.; Sari, A, W, I.; Mulyaningsih, E.; Utami, P.; Yunis, Y.; Studi alterasi hidrotermal bawah permukaan di lapangan panas bumi "BETA", Ambon dengan metode Petrografi. Prosiding seminar nasional kebumian ke-7. Jurusan Teknik Geologi. Fakultas Teknik. UGM. Yogyakarta. 2014.

[5] Curewitz, D., Karson, A, J. Structural settings of hydrothermal outflow: Fracture permeability maintained by fault propagation and interaction. J. of Volcanology and Geothermal Research. vol. 79, 1997, pp. 149-168,.

[6] Shimada, K., Yoshikazu, S., Hideo, A., Noriaki, U., Koichiro, F., Mitsuru, H., Hiroshi, N., Shatei, I., Yoshimi, F., Kenji, S., Kenji, F. Final Report of "Beta" Geothermal Field, JICA Preparatory Survey for "Beta" Geothermal Field, Unpublished, 2011.

[7] Nasution, A., Aviff, M., Nugroho, S., Yunis, Y., Honda, M. The preliminary conceptual model of Tolehu geothermal resource, Based on Geology, water Geochemistry, MT, and Drilling. 2015. Proceedings World Geothermal Congress. Melbourne, Australia.

[8] Moghaddam, M, M., Mirzaei, S., Nouraliee, J., dan Porkhial, S. Integrated magnetic and gravity surveys for geothermal exploration in Central Iran, Arab. J. Geosci., vol. 9, no. 7, 2016, pp. 1-12.

[9] Linthout, K., Helmers, H. Pliocene obducted, rotated, and migrated ultramafic rocks and obduction-induced anatectic granite, SW Seram and Ambon, Eastern Indonesia. Jornal of Southeast Asian Earth Science, V.9, 1994, pp 95-109.

[10] Charlton, R.T. The Pliocene-Recent Anticlockwise Rotation of the Bird's Head, the Opening of the Aru Trough-Cendrawasih Bay Spenochasm, and the Closure of the Banda Double Arc. In Proceedings of the IPA Thirty-Fourth Annual Convention an Exhibition, Jakarta, Indonesia, 18-20 May 2010. 
[11] Lewerissa, R. Analisis Tensor Gradien Gravitasi Lengkap dan Data Magnetik Bumi untuk Pemodelan Geologi Bawah Permukaan Sistem panas Bumi di Desa Suli dan Tulehu Kabupaten Maluku Tengah. Disertasi S3 Fisika UGM. Yogyakarta, 2019.

[12] Baranov, V and Naudy, H. Numerical calculation of the formula of reduction to the magnetic pole. Geophysics; 1964; 29: 67-79.

[13] Nouraliee, S,J., Porkhial, M., Moghaddam, M, S., Mirzaei, D., Ebrahimi., Rahmani, M, R. Investigation of density contrasts and geologic structures of hot springs in the Markazi Province of Iran using the gravity method', Russ. Geol. Geophys., vol. 56, 2015, pp. 1791-1800.

[14] Hsu, S., Sibuet, J., dan Shyu, C. High-resolution detection of geologic boundaries from potential-field anomalies: An enhanced analytic signal technique. Geophysics 61, 1996, pp 373-386.

[15] Roest, W.R., Verhoef, J. dan Pilkington, M.. Magnetic interpretation using the 3-D analytic signal. Geophys, 57: 1992, pp 116-125.

[16] MacLeod, I., Jones, K., dan Dai, T.,. 3D analytic signal in the interpretation of total magnetic field data at low magnetic latitudes. Explor. Geophys. 24, 1993, pp 679-688.

[17] Yadav, P.K., Adhikari, P.K., Srivastava, S., Maurya, V.P., Tripathi, A., Singh, S., Singh, R.K., dan Bage, A.K.,. Lithologic boundaries from gravity and magnetic anomalies over Proterozoic Dalma volcanics. J. Earth Syst. Sci. 2018, 127, 17.

[18] Li, X., dan Chouteau, M. Three-dimensional gravity modeling in all space. Survey in Geophysics, 19, 1998, pp 339-368.

[19] Macleod N, I dan Ellis,G, R. Magnetic Vector Inversion, a simple approach to the challenge of varying direction of rock magnetization. ASEG-PESA. Australia, 2013.

[20] Lewerissa, R., Sismanto, S., Setiawan, A., Pramumijoyo, S. The Study of Geological Structures in Suli and Tulehu Geothermal Regions (Ambon, Indonesia) Based on Gravity Gradient Tensor Data Simulation and Analytic Signal. Geosciences 2018; 8, 4. 